\title{
The State of Local Government and Service Delivery in Nigeria: Challenges and Prospects
}

\author{
Aderonke Majekodunmi
}

\section{Abstract}

ocal government creates an
appropriate and conducive environment for the people at the local level through efficient and effective service delivery. The value of local government in a country is inestimable because it is an indispensable arm of government. As a result, the link between the qualities of service that citizens enjoy is very significant. The article examines local government and effective service delivery with special reference to Nigerian local governments. It notes that Local government is the closest government to the people at the grassroots level, so it is expected to play significant roles in providing the social services for the people in order to improve their standard of living. But in Nigeria, the impact of local government is so far limited, especially with regard to improving service delivery. The article observes that despite the strategic importance of local government to the development process through effective service delivery, there has not been much development in most local governments in Nigeria. The article recommends that local governments in Nigeria need adequate autonomy that can facilitate their operations and development of the localities through effective service delivery.

Keywords: Local Government, Service Delivery, Development, Nigeria. 


\section{INTRODUCTION}

In all emergent states, local government has become the main fundamental instrument for the acceleration and sustenance of development. Local government is widely acknowledged as a viable instrument for development and for the delivery of social services to the people. It is believed that this third tier of government is strategically placed to fulfil this condition as a result of its proximity to the rural people, which enhances its ability to easily articulate and aggregate the demands of the people (Ugwu, 2008). As observed by Agagu (2004), the need to catalyze balanced development, maximize citizens' participation, and stimulate government responsive service delivery necessitates the creation of the local government. The local government serves as a form of political and administrative structure facilitating decentralization, national integration, efficiency in governance, and a sense of belonging at the grassroots. The local government is a unit of administration all over the world.

The Local Government is the closest tier of government to the people in Nigeria, yet the resident population in it is denied the benefits of its existence. This is evident in the environmental state, deteriorating public school buildings, poor market facilities and lack of health care centres. The failure of the Local governments in the area of service delivery has made the citizens to lose trust in government as an institution. In some areas, council officials are better known for the harassment of citizens than service delivery (Olusola, 2011). The major concern here is the extent to which goods and services are delivered to local citizens in the right quantity and at the right time.

The constitution assigns service delivery responsibilities to the three tiers of government with the states and local governments playing the most significant role in the delivery of basic services such as education, health, housing, water, and waste disposal services. Given the Millennium Development Goals and the huge resources that have accrued to the various levels of government, it is pertinent to review the performance of service delivery since the country's return to democratic rule in 1999.

\section{The Concept of Local Government and its Key Features}

There is the need to explore what exactly is meant by local government. It is difficult to find a single and comprehensive conceptualisation of local government acceptable to both the developing and developed countries of the world. Local government is a government at the grassroots level. According to Ojofeitimi (2000), the word "local" connotes that councils are meant for small communities and the word "government" means that they have certain attributes of government. The concept of Local Government may be seen as a segment of a constituent state or region of a nation state, established by law to provide public services and regulate public affairs within its area of jurisdiction (Ikelegbe, 2005). As King (1988) observes, the local government is universally found in modern politics, although it goes by various appellations. Its legitimacy lies in 
its official tasks to represent the interests or wishes of the local inhabitants and to administer to their needs. Founded on democratic ideals, it is required that they be given an opportunity to control their affairs at this level, especially since this is the point at which their interests and welfare are most likely to be directly affected.

Local government is a government at the grassroots level of administration, meant for meeting peculiar grassroots need of the people (Agagu, 1997). Lawal (2000) defines local government as that tier of government closest to the people, which is vested with certain powers to exercise control over the affairs of the people in its domain. Local government as a system of public administration at a local level, charged with the responsibility of bringing the people at the grassroots closer to the government. He however, regretted that a critical survey of local governments in Nigeria today slows at most the same scene; that is, they are living in the shadow of the federal government that have resulted to the abysmal failure of the system (Usman, 2010).

Local government is a politico-administrative arrangement which entails the devolution of authority to plan, make decisions and manage public functions from the central government to subordinate organisations, agencies or units of government, either geographically or structurally (Anyanwu, 1999). Emezi (1984) on the other hand perceived local government as "system of local administration under local communities that are organized to maintain law and order, provide some limited range of social amenities, and encourage cooperation and participation of inhabitants towards the improvement of their conditions of living. It provides the community with formal organizational framework which enables them to conduct their affairs effectively for the general good.

From the above definitions, the following basic characteristics of local government can be identified; it is a tier of government which is subordinate to central or regional government. It involves both the administrative and political processes of governmental power. Its area of authority is delimited by the statute establishing it. It has constitutional or statutorily mandated power to perform certain legislative, administrative and judicial functions. Its council is made up of elected representatives who are responsible to the electorate in the discharge of the functions assigned to them. Within the limit of its power, it has legal autonomy to make policies, to prepare its own budget, to hire its own staff and to execute its own policies; and it has a corporate personality.

It is the unique way in which it combines the political and the administrative roles, or the democratic and service agency functions, that characterizes local government. A local government is a legal entity that allows residents of a defined geographic area to provide services of a common interest. But it is also a democratic institution, governed by an elected council accountable to the residents and to which they can address their collective concerns. It is an instrument that residents can potentially use to influence positive change and development in their local community.

Ola (1984) identifies three schools of thought in the functional conceptualization of the local government as a governmental unit. These include democratic-participatory school, developmental school, and efficient service delivery school. In this article 
attempt is made to examine efficient service delivery school as a result of its importance to this study.

The advocates of efficiency services believe that the crux of this theory is that the main purpose of local government is to provide services to the local people. The efficiency services theory also stipulates that the smallness of the population allows for efficient provision of the basic social amenities. It also allows for flexibility in decisionmaking and implementation. In addition, the theory stipulates that local government exist to articulate and aggregate the interests and aspirations of the people for better and more efficient services. However, from the perspective of the efficiency-services school, the appropriate functional focus of local government should be the provision of services, and its success or failure has to be judged by this yardstick (Ola, 1984). The theory argues that what is central and important to the people is the knowledge and articulation of the problem confronting the people and finding appropriate solutions to the problems. The theory further argues that since the officials of the local government councils are indigenes of the areas, they are in a better position to understand the needs of the people and provide efficient services for their welfare. The proximity of the local government to the grassroots makes it especially suited to provide certain functions far more efficiently and in a more cost effective manner than the much more remote government at the higher level. Such functions should be allocated to the local governments with powers, resources and the necessary autonomy to handle them. This then is not a mere decentralization of central governmental authority, for if it is, it will require a degree of routine supervision by the central or state government that will not be conducive efficient service delivery, the raison d'être of the local government as a unit of government.

\section{Effective Service Delivery}

Effective service delivery involves a clear understanding of the specific services an organization provides, and its target customers. Understanding the service characteristics enhances how their customers see the services an organization provides. According to Nash and Nash (2004), effective service delivery is the provision of services to a buyer in such a way the buyer's expectations can be met or exceeded while, at the same time, the business remains viable. Effective service delivery is rendering services that correspond to the customers' desires, needs and expectations. This concept emanates from the perceived need to treat members of the public that require government services like a private-sector entrepreneur would treat his/her customers.

This is against the backdrop that a major obstacle to efficient and effective delivery of government services is the attitude of public servants to members of the public who are their customers (Fagbemi, 2006). A customer is the direct recipient of a service through

dealings with the service provider. Customers can be internal or external. Internal customers refer to those that receive services from other divisions within the same 
organization, while external customers are those outside the service providing organization.

\section{Nature and Evolution of Local Government System in Nigeria}

Local government is one of man's oldest institutions. The earliest form of local government existed in the form of clan and village meetings. In fact, democracy itself originated and developed along the lines of local government initiatives in the ancient Greek city states (Agbakoba \& Ogbonna, 2004). The history of local government system in Nigeria could be traced back to the pre-colonial period when powerful empires and kingdoms existed in Nigeria, such as, Oyo Empire, Borno Empire, Sokoto Emirate, Jukun Kingdom, Nupe Kingdom, and Igala Kingdoms, among others. These empires and kingdoms had other smaller districts, wards, towns and villages which were subjected to their authorities. The subordinate governments operated their own unique administration suitable for their cultural and religious needs and aspirations. The bulk of the administrative activities of these kingdoms and empires took place at these levels. This form of administration could aptly be referred to as Local government.

The advent of British colonial administration in Nigeria brought about a change in local government administration in which the method of leadership changed from the traditional to the British colonial government. The colonial administration of local government that was established was based on Indirect Rule system. This required that administration at the local level should be carried out through the existing traditional rulers and institutions. In the areas where there were no existing traditional rulers, and/or institutions, like in the South East, new ones were created. This led to the establishment of Native Authority in its most rudimental forms. The Native Authority Ordinance promulgated in 1910 which gave impetus to the system of indirect rule and recognised the traditional rulers as Sole Authority. The main function of the traditional ruler was to maintain law and order (Asaju, 2010).

In pre-colonial times, the antecedent of local government was the native administration established by the colonial administration. It was meant to adapt to purposes of local government structures already present in the institutions of the various ethnic groups. The idea was for these existing structures to develop into effective tools of government ready for use (after pertinent modifications) by the colonialists. The Native Administration was charged with the collection of taxes, maintenance of law and order, road construction and maintenance, and sanitary inspection, especially in township areas (Diejomaoh \& Eboh, 2010). The local government system has been a major feature of the Nigerian government and politics since colonial rule; though over the years, there have been changes in name, structure, and composition, while the system was operated differently all over the country (Agagu, 2004). It was on this premise that the rising tide of progress, growth, and development experienced in the local government was based. 
Available record shows that the first local administration ordinance № 4 of 1916 which was designed to evolve from Nigeria's old institutions best suited form of rule based on the people's habit of thought, prestige and custom (Bello-Imam, 1990). Ayo (1995) observes that the Nigerian local government system had undergone series of metamorphosis. He noted that the system has been restructured, re-organized and revitalized depending on the regime in power as well as the nature and level of interest of such regime in local government administration. Administration systems at the grassroots level in Nigeria had always been in operation since time immemorial among the various people now christened Nigeria, even before the colonial masters set their feet on the soil of Nigeria (Awofeso, 2004). Put differently, it is not debatable that the history of local government system in Nigeria is older than the advent of the erstwhile colonial masters. Colonialism, however, helped to widen the course of history of Nigerian administration systems as it contributed significantly to the evolution of local government in the country. This explains why many scholars are of the view that local government in Nigeria emerged from the British colonial administration in the country.

The 1976 local government reform, carried out by the military administration of General Obasanjo, brought about uniformity in the administrative structure of the system. The reform introduced a multi-purpose, single tier local government system for the whole country (Ajayi, 2000). The local government is essentially created as a viable political and administrative organ for the transformation of all communities and for delivery of essential services to the citizens. The primary purpose of the local government and the basis for its existence is to create a mass development impetus to the grassroots transformation (Adeyemo, 1995). The current platform for local government practice in Nigeria came into existence in 1976. It created a uniform structure of an elected council with specific functions and financial base which drew directly from the federation account. The new platform represented a departure from the myriad of practices, often with regional flavours, which had evolved under colonial rule from the Native Authority system.

The Local Governments underwent their first major reform in 1976 during the military administration of General Olusegun Obasanjo. These reforms formed the foundation of the present-day local government system, and were attempts to restructure the Local Government administration to a form fitting for modern society. The fundamental result of the 1976 reforms was to introduce a uniform system of local government administration throughout the country. It was based on a conviction that a strong local authority with clearly defined roles and responsibilities in a power-sharing relationship with the states is an institutional imperative. Based on the 1976 reforms, local government became recognized as a tier of government entitled to a share of national revenue consequent on its constitutionally allocated functions (Imuetinyan, 2002).

Since these reforms, successive governments have tinkered with the local government structure with a view of enhancing its capacity for good governance. Fundamentally, the local government is created to serve the rural communities. The 
local government is expected to mobilize and harness local resources and ensure their effective utilization, with the support of the state and federal governments.

\section{An Overview of Local Government and Service Delivery in Nigeria}

The local government is essentially created as a viable political and administrative organ for the transformation of all communities and for delivery of essential services to the citizens. Local government plays a central role in enabling the achievement of development at the grassroot level. Governments should therefore continuously seek new and better ways to build service institutions that have the capacity to champion and advance the course of development. Local government must create an appropriate and conducive environment for the people at the local level through efficient and effective service delivery. It is responsible for the creation of an appropriate and conducive environment in which all sectors of the economy can perform optimally, and it is this catalytic role of local government that propelled governments all over the world to search continuously for better ways to deliver their services (Aluko, 2011).

By law, local governments are mandated to provide the following public goods and services: establishment and maintenance of roads within the towns of the district, including sidewalks, street lights, and street drainage system, construction of water reservoirs in towns and villages, construction and management of primary schools. Other essential functions include the construction and management of centres for the care of the mother and the child, physical planning of the settlements of the districts and registration of the immovable property, solid waste collection and disposal, food and livestock markets, slaughterhouses, management of self help projects, registration and maintenance of civil register, and issuing business licenses, among others.

A key purpose of local government is to promote the well-being and quality of life of citizens and communities through effective and accountable representation and efficient performance of functions and delivery of services. Local authorities have certain advantages over more centralised organisations. The constitution assigns service delivery responsibilities to the three tiers of government with the states and local governments playing the most significant role in the delivery of basic services such as education, health, housing, water, and waste disposal services. Local government's commitment to the principles of quality customer service have been illustrated in recent years through a variety of practical developments, such as extending opening hours of operation, improving facilities, providing more accessible services, e-government initiatives, and published service standards, in many cases through public customer charters and customer service actions plans.

In Nigeria, government's services are described as inefficient, ineffective, and never meeting clients' demand on time. When the present government came into power, it had vowed to change the lives of the citizens of the country for the better. It became necessary to change the methods of delivering services to the people. For the government to be able to bring this ideal to reality, it was then urgent to move away 
from the conventional approaches to public service delivery where government was the sole provider of services to the public and seek alternative, cost effective and efficient ways of delivering services to the public in a manner prescribed by the Constitution.

Nyamukachi (2009) describes three ways in which government failure to deliver services through local government can be interpreted: inability to achieve the goals that government has planned and budgeted for; failure to deliver on unplanned and unbudgeted goals; this becomes difficult to achieve as government's plans are linked to the budget. If not planned for, it means it is not budgeted for and therefore it will not be realised during that time. This, however, reflects on the government's planning process and the level of community involvement. The inability to render quality service is evident by the number of poor quality of services, the number of clinics that are not properly equipped and the quality of roads that are constructed.

Poor service delivery and governance remains an overwhelming challenge in most local government in Nigeria. Of major concern is the degree of corruption, institutional capacity constraints relating to appropriate skills and staff, lack of transparency, dysfunctional of ward committees, lack of accountability by councillors and municipal officials, lack of public participation in issues of governance, failure to comply with municipal legislation and other by-laws, failure to prioritize community needs and budgeting processes not aligned, tensions between the political and administrative sections of the municipalities and weak financial viability of local governments.

The present 1999 Nigeria Constitution recognises the local Government as the third tier system of government. However, nearly all the local governments in Nigeria are either crippled by the force of the state or wilfully not performing to people's expectation in the country. One then ask these among many questions: what is the role of the local government and what is the role of the state and how can it improve the frame work within which local government operates in line with the new public-privatepartnership of the Federal Government?

Describing the requirements of the access principle for effective public service delivery, Batho (2006) explains that all citizens should have equal access to the services to which they are entitled. The openness and transparency principle has it that citizens should be told how national and provincial (states, local governments) departments are run, how much they cost, and who is in charge.

\section{Challenges to Effective Service Delivery at the Grassroot Level in Nigeria}

It is an irony of fate that the military induced reforms in the Nigerian Local Government has its attendant contradictions since the military structure is essentially hierarchical, thus the operation of Local Government cannot be isolated from such contradictions that characterized military hegemony. Adeyemo (1996) opined that the Nigerian Federalism remains a formidable problem is evident in the various contradictions of military rule and the decrees they have spurned. One of the greatest challenges is that of 
limited capacity. Although their strength and capacity have grown steadily since independence, local governments are still not able to perform their roles and discharge their functions much as expected. Their autonomy is limited and they remain unable to manage essential functions without assistance from central government.

One of the most serious problems currently militating against local government is on the exact status of local government under 1999 constitution of the Federal Republic of Nigeria. The problem according to Adeyeye (2001) arises out of the various provisions in the constitution, which tend to contradict or impair one another. Similarly, some of these provisions are blatantly ambiguous, and if stretched, could easily result into operational or functional stolidity. Similarly, the continuous overbearing role being exercised by the states poses a tremendous threat to the autonomy of Local Government. These can be seen within the realm of various contradictory rules, instructions, and supervisory powers passed down to the local councils, some of which are outside the constitutional jurisdictions of the Local Governments. Local government authority in Nigeria lacks the requisite financial autonomy desirable and necessary for effective management of their financial resources. The much touted local government autonomy envisaged by the theory and practise of fiscal federalism in Nigeria is more or less a political gimmick. That is precisely why it is a myth rather than reality (Akindele \& Olaopa, 2002).

To talk of absence of effective service delivery in local government is to talk of the presence of corruption in the local government system in Nigeria. Local governments have become vineyard of corruption where council political officers sit to share the statutory allocation from the federation account. Instead of being used for public good, the allocations are diverted to personal use. Indeed, since the advent of local government in Nigeria in the 1950s, Odion-Akhaine (2009), noted that the social problem of corruption has dogged it. To be sure, local government is no longer local government but local corruption. It has thrived, progressed, and flourished unabated in Nigeria. Corruption has taken the central stage in most local governments. This tendency is obviously a national malady. Most internally generated revenues do not go to the local government account. It is viewed by patrons of ruling parties and their clients as political reward for 'faithfully enabling the party to win or remain in office'. The sources of these revenues are regarded as "Cash Point" for daily reimbursement of 'operators'. At the end of the day, the local governments are worst off financially. Little wonder, they now depend on the federal and state governments for funds to at least, pay the monthly salaries and wages of their workers. It may not be off the mark to suggest that what most local governments do in recent times is merely source for money to pay their workers salaries and wages. All other developmental projects and programmes are put on hold 'until the financial condition of the council improves', the local authorities would refrain.

Corruption has been institutionalized to the point of accepting it as part of our system. Albeit, corruption is ubiquitous; it is found all over the world, but the degree of its manifestation varies form system to system. At the grassroots level, corruption has been canonically accommodated, entertained, and celebrated within the system. In the 
local government setting, corruption is misnomer labelled and euphemistically referred to as "EGUNJE" (a slogan which means "illegal offer" in Nigeria). Kolawole (2006) laments this situation when he opines that "in spite of the establishment of the Independent Corrupt Practices and other related Offences Commission (ICPC), corruption still thrives in our society." In his analysis, Kolawole was of the view that the lack of funds was no more a constraint on local government performance, but a mismanagement and misappropriation of the funds accruable to it.

Adedeji (1970) blames the ineffectiveness of local administration on the following reasons: lack of mission or lack of comprehensive functional role; lack of proper structure (i.e. the role of local governments in the development process was not known); low quality of staff; and low funding. According to him, these problems lead the local governments into a vicious circle of poverty because inadequate functions and powers lead to inadequate funding which result in the employment of low skilled and poorly paid staff.

Another problem of local government in Nigeria is inadequate finance to carry out its statutory responsibilities. Local governments do not posses viable sources of generating funds especially the rural based ones. They therefore depend heavily on fund allocations from the federation account for the purpose of carrying out their basic responsibilities. This problem from the viewpoint of Enemuo (1999) arises from their incapacity to raise funds internally and insufficient transfers from the central governments. Local governments in the country lack the required finance to make their impact felt in every community under their jurisdiction. This has greatly affected the effectiveness and performance of local government in Nigeria.

Local level political leadership has a significant role in strengthening local government. Local level leadership has grown since independence but the capacity of many councillors leaves much to be desired. The grassroots organizations such as Community Development Associations need to be more active, and community participation strengthened. Productivity of local level organizations remains another challenge despite various productivity enhancing measures such as work improvement teams and performance management systems. Declining standards of integrity are also a matter of concern (Sharma 1998). The administrative machinery's accountability to the people needs to be strengthened, and administration needs to become more responsible, responsive and sensitive to peoples' needs and expectations.

It is common knowledge that some staff members of local government councils are not recruited solely on the basis of the possession of requisite knowledge and experience. Political considerations and patronage in most cases take over their recruitment policies, thus making lack of qualified staff to manage the books of the local governments a grave problem.

Employment at local government level in Nigeria is based on favouritism, nepotism, ethnic and political consideration and other extraneous factors that replaced and displaced competence, qualification, experience and performance. Entrance into the local government staff forum is usually through junior staff cadre as it is the 
compensatory tool of the chairman as necessitate by spoils system and prebendalism. This grade level 01-06 whose payment status is as low as N24,000.00 (US\$150) at most is naturally not suitable for any skilled worker. A graduate of any field, all things being equal, will not listen to such pronouncement let alone accepting the offer. If he does, thanks to unabating unemployment, he must, as a matter of necessity, device another means of adding up to his salary, which ordinarily cannot meet his physiological needs. Therefore, the local government suffers (Emeh, et al 2009). Onyishi (2002) blamed the problems of personnel department of the local government on overcentralization hence lumping seldom makes staff assessment efficient. Onah (2002) pointed at political interference from the states and the influence of ethnicity, favouritism and nepotism. Majorly, irregular payment of staff salaries and total absence of fringe benefits and physical working conditions which are usually very poor are all awful conditions impacting negatively on the personnel management of local government councils.

\section{The Way Forward: measures to meet the challenges}

Effective service delivery must be tailored to the circumstances of the location. This requires credible evidence based measures and sound economic reasoning. The best way to make effective policy is to make sure that its guiding principles are evidence based, learned from experience elsewhere, in addition to pragmatic mechanism to expand the evidence base for Africa.

Efforts to strengthen service delivery should therefore be directed at building the capacity of local government organizations. This requires clarity of policy and a commitment to its implementation. People have to be taken on board and policies for them have to be made with them. The local authorities must ensure that their finances are not mismanaged and standards of integrity and accountability are maintained. There has to be zero tolerance for corruption and mechanisms of control and accountability have to be strengthened. The performance of local level political leaders could be strengthened through organization of workshops, seminars and published material which could enhance their knowledge and understanding of their expected roles.

Accountability and transparency must be encouraged and promoted in the local government system so as to attain good governance for effective development at the grassroots level. Corruption must be deterred and punished in the local government system to enhance efficient and effective service delivery at the grassroots level. There is need for a change of political values by the dominant political elite, to accord local governments the needed autonomy to carry out their responsibilities. There is no doubt that Nigeria has come a long way with the constitutional inclusion of local government as a third level of government not solely dependent on the whims and caprices of the states. While the motive of the constitutional recognition of local governments which in the main is to ensure local government autonomy may not have been fully realized in Nigeria due to the obvious failure of the higher level governments especially state governments to respect the provisions. 
Local governments in Nigeria need adequate autonomy that can facilitate their operations and development of their localities. This should emanate from institutionalized democratic process of elections for representative local government councils as and when due. This should be in line with what obtains at the State and Federal government levels where elections are timely conducted. Adequate autonomy should be manifestly accorded local governments in other areas such as finance, revenue generation and expenditure, personnel administration and development matters. The State Joint Local Government account should be abolished. As a way forward, a leaf could be borrowed from the way the federal government tried to tackle the issue in 1988. There should be capacity building for local councils to take advantage of modern tools of local governance that are being developed worldwide. This must combine the political and administrative cadre of the councils.

Local governments need to have adequate and sustained sources of revenue, so that they can be responsive to the needs of their communities. Revenues are not presently collected in an efficient manner, though resistance from tax payers cannot be ruled out. Financial management practices employed at the local governments was, until recently, quite primitive. Councillors and local government staff should realize that, by law, they are mandated to provide services to the communities in their localities; hence, greater service delivery must be planned and budgeted. Specifically, the systematic collection and proper disposal of garbage should be given utmost attention, as it grossly affects the health and well-being of the society.

\section{Conclusion}

In ensuring effective local government administration in Nigeria, it is important that the local government should rationalize its expenditure patterns so as to, at least, achieve optimum performance. It is indisputable that in Nigeria the local government even though it might have gone through several stages of development has come to stay as the third tier of government. Also, from conception till date, the relevance of local government areas in the scheme of governance in Nigeria has not been in doubt. It is seen as a channel through which governance and development at the federal level can quickly reach the people at the grassroot. Local governments should also capitalize on the willingness of the local communities and systematically plan and finance quick impact projects that are sustainable and beneficial to all. The recent practice of local governments in enhancing service delivery capacity should therefore be sustained and strengthened. 


\section{List of References}

- Adedeji, A. 1969. Nigerian Federal Finance. London: Hutchison.

- Adeyemo, D.O. 1995. Sustaining Democracy in Nigerian Local Government: The Role of Legislatures. In Akindele, S. \& Ajila, C. (eds). Contemporary Issues in the Social Sciences. Ile Ife: Obafemi Awolowo University Press.

- Adeyemo, D.O. 1996. Federalism and the Logic of Local Government Autonomy in Nigeria. Nigerian Journal of Local Government Studies, 16. December 1996 O.A.U. lle-life.

- Adeyeye, M. 2001. Reinventing the Grassroots Level: The Challenge of Governance in Nigeria. Paper presented at Consultative Workshops on the Reform of Local Government System and Administration in Nigeria, at ACDESs, ljebu Ode, November 25-27.

- Agagu, A. 2004. Continuity and Change in Local Government Administration and the Politics of Underdevelopment. In Agagu, A. \& Ola, R. (eds). Development Agenda of Nigeria State. Ibadan: Fiag Publishers.

- Agagu, A.A. 1997. Local Government. Kolawole (ed). Readings in Political Science. Ibadan: Dekaal Publishers.

- Agbakoba,O. and Ogbonna, H. 2004. Local Government Administration and Development in Nigeria. Lagos: Hurilaws.

- Ajayi, K. 2000. Justification and Theories of Local Government. In Ajayi, K. (ed). Theory and Practice of Local Government. Ado-Ekiti. Department of Political Science, University of Ado-Ekiti.

- $\quad$ Akindele, S.T. and Olaopa, O.R. 2002. Fiscal Federalism and Local Government Finance in Nigeria. upan008121.pdf(application/pdfO... Assessed on 10 March 2013.

- Anyanwu, J.C. 1999. Fiscal relations among the various tiers of government in Nigeria. In Fiscal Federalism and Nigerian's Economic Development. NES Selected Papers Presented at the 1999 Annual Conference Ibadan.

- Anyanwu, U.D. 1996. Local Government Administration. in Elaigwu, J. Isawa and Uzoigwe, G.N. (eds). Foundations of Nigerian Federalism: 1900-1960. Abuja: National Council on Intergovernmental Relations. 118-138.

- Asaju, K. (2010). Local Government Autonomy in Nigeria: Politics and Challenges of the 1999 Constitution. International Journal of Advanced Legal Studies and Governance. 1(1):98-113, 
- Awofeso O. 2004. Issues in Local Government Administration in Nigeria. Lagos: Lis Johnson Resources Publishers.

- Ayo, S.B. 2003. The Evolution of the Nigerian Local Government System, in Awotokun, A.M. (ed.) New Trends in Nigerian Local Government lle-Ife: OA.U Press Ltd.

- Bello-Imam, I.B. 1990. Local Government Finance in Nigeria. Ibadan: NISER

- Diejomaoh, I and Eboh, E. 2010. Local Governments in Nigeria: Relevance and Effectiveness in Poverty Reduction and Economic Development. Journal of Economics and Sustainable Development. 1(1): 12-29

- Emezi, C. 1984. Local Government in Historical Perspective. Nigerian Journal of Public Administration and Local Government, 2(2): 50.

- Enemuo, F.C. 1999. Decentralization and Local Government: Models, Principles and Purpose. in Anifowose, R and Enemuo, F. (eds). Elements of Politics. Lagos: Malthouse Press Ltd.

- Ikelegbe, A.O. 2005. The Local Government System and Grassroots Development in Nigeria: Issues, Problems and Challenges. in Onokerhoraye, Andrew G. and Omuta, Gideon, (eds). Perspectives on Development: A Book in Honour of Pius Oghenerukohwo Sada. Benin City: Centre for Population and Environmental Development.

- Imuetinyan, F.O. 2002. Issues in Nigerian Government and Administration. Benin City: Denvic Publishing Company.

- King, M.C. 1988. Localism and Nation Building. Ibadan: Spectrum Books.

- Kolawole, D. 2006. A Paper delivered at the event marking the Local Government day in Ondo state, Nigeria. May 26.

- Lawal, S. 2000. Local Government Administration in Nigeria: A Practical Approach. Ibadan: University Press Limited.

- Nyamukachi, P.M. 2004. Options for Urban Service Delivery in South Africa with Special Reference to the Tshwane Metropolitan Municipality. University of Pretoria. (M Admin).

- Odion-Akhaine, S. 2009. Local Government and Nation-building. in OdionAkhaine, S. (ed). Local Government Administration in Nigeria: Old and New Visions. Lagos: Center for Constitutionalism and Demilitarization.

- Ojofeitimi, T. 2000. Managing at the Grassroots: Local Government and Rural Development in the $21^{\text {st }}$ Century. Lagos: Centre for Management Development.

- Ola, R.F. 1984. Local Administration in Nigeria. London: Kegan Paul International 
98 The State of Local Government and Service Delivery in Nigeria

- Olusola, O.O. 2011. Boosting Internally Generated Revenue of Local Governments in Ogun State, Nigeria: A Study of selected Local Governments in Ogun State. European Journal of Humanities and Social Sciences. 8(1)

- Onah, F. O. 2008. Human Resource Management. 2nd Edition. Enugu: John Jacob's Classic Publishers Ltd.

- Onyishi, A. O. 2002. Organization of Personnel Functions at the local government level in Nigeria. in Ezeani, E. O. and B. C.; Nwankwo (eds). Human Resources management in the local government system in Nigeria. Nsukka; APExpress Publishers

- Sharma, K.C. 1998. Toward a More Ethical and Accountable Public Bureaucracy. in R. Hope and G. Somolekae (eds.). Public Policy and Administration in Botswana. Kenwyn, Juta and Co.

\section{AUTHOR'S CONTACT \\ MAJEKODUNMI, Aderonke \\ Department of Political Science \\ Faculty of Social Science \\ University of Lagos \\ Nigeria \\ E-mail: ronky66@hotmail.com}

